\title{
PERFORMING GENDER AND DEVOTION IN THE PEÑAFRANCIA FESTIVAL IN THE PHILIPPINES
}

\author{
Sir Anril P. Tiatco \\ Department of Speech Communication and Theatre Arts \\ University of the Philippines Diliman \\ Quezon City, Philippines \\ (sptiatco@up.edu.ph) \\ DOI: https://doi.org/10.22452/jati.vol25no2.7
}

\begin{abstract}
The Festival of Our Lady of Peñafrancia is celebrated on a Sunday after the octave of 8 September. Housed at the Peñafrancia Basilica Minore, the image of the Peñafrancia is considered the patroness of the entire Philippine region of Bicol. In the essay, the Peñafrancia is described as a theatricalised devotion where devotees are transformed into a frenzied ensemble that normalises masculinity as a privileged norm. However, digging deeper into the festival's peculiarity, the normalisation of masculinity is only incidental because the gendering, in fact, idealises and celebrates a figure of a woman. The idealisation and celebration of the woman-figure is asserted to have a precolonial root. In the end, it is argued that the Peñafrancia is a manifestation of a cultural community in which the pre-colonial lifeways of its members are recuperated through expressive bodily movements. At the same time, the legacy of Hispanic Catholicism is decolonised through rearticulating an indigenous past.
\end{abstract}

Keywords: cultural performance, Philippine Catholicism, panata, pre-colonial lifeways, surrogation, figuration

\section{Introduction}

"Kakaibang debosyon, kailangan mo siyang ma-experience. Para kang lumangoy sa isang dagat na puno ng kalalakihan" [It's a very unique devotion. You have to experience it yourself. It's like swimming in a sea of men], exclaimed a Bicolano colleague who is also a devotee of the Lady of Peñafrancia. A Bicolano is a native of the Bicol region in the Philippines and the Lady of Peñafrancia is the region's 
patroness. On the occasion of the patroness's feast day in 2015, my colleague brought me to his hometown in Naga City to witness what he enthusiastically proclaimed as the most peculiar Catholic tradition in the contemporary Philippines. After an almost 12-hour bus ride from Manila, we arrived in the city just in time for the first activity of the festivity and devotion.

We stayed on the roof deck of a restaurant located at the corner of J. Luna and P. Burgos Streets and across the Plaza Rizal. According to him, the roof deck was a strategic location to see the festivity. It was already 3 PM when a surge of men began flooding the streets of J. Luna and P. Burgos. People from the plaza were pushed toward its innermost section as the waves of men moved forward. It was only during that surge that I comprehended the insistence of my colleague to see the ritual and festival from above as it was not safe to stay on the ground.

The Festival of Our Lady of Peñafrancia (locally called Ina, loosely translated as mother) is celebrated on a Sunday after the octave of 8 September (the Birth of the Blessed Virgin Mary in the Catholic calendar). Housed at the Peñafrancia Basilica Minore (popularly called the Shrine of Our Lady of Peñafrancia), Ina is considered the patroness of the entire Bicol region, composed of six provinces (Albay, Camarines Sur, Camarines Norte, Sorsogon, the islandprovinces of Catanduanes and Masbate) and seven cities (namely, Legazpi, Naga, Iriga, Tabaco, Ligao, Sorsogon, and Masbate). One of the poorest regions in the nation, the largest component of the region's economy is agriculture (Cannell, 1999). Annually, devotees of Ina hold a pilgrimage to Naga City to celebrate and honor her divinity. More so, Bicolanos devotees participate in the festival to pray for the protection of their agricultural products, especially since the region is one of the Philippine gateways of typhoons and storms coming from the Pacific Ocean.

The festivity is a month-long celebration of both state-sponsored and Church-led activities. Many of the state-sponsored events (led by both the Office of the City Mayor in Naga City and the Office of the Governor of Camarines Sur where Naga City is located) are competitions where cities, municipalities or sometimes universities from all over the region compete with each other in sports, dance and music. For instance, in 2017, a marching band competition was held. The competitors were high schools from the region. The highlight of the different state-led events is the Miss Bicolandia (est. 1982), the longest running beauty pageant in the region, boasting of winners and runners-up who have been successful in national pageants such as Binibining Pilipinas, Miss PhilippinesEarth and Miss World Philippines. 


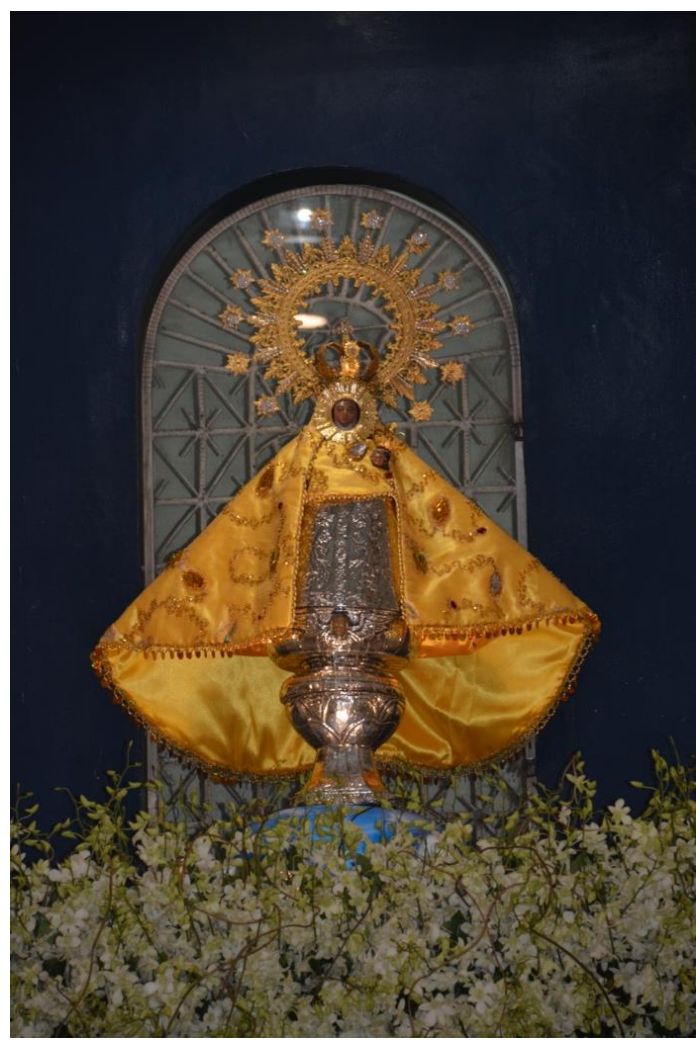

Figure 1: The replica of the image of Our Lady of Peñafrancia or Ina for the Catholic community members of the Bicol Region. The same image is paraded onto the streets of Naga City during the 9-day ritual-festival in her honor (Photo: Sir Anril Tiatco)

As one of the most anticipated Catholic festivals in the archipelago, the Church celebrates the Peñafrancia for nine days preceded by a novena, or a nineday prayer. On the first day of the novena, a replica of Ina (together with the image of the Divino Rostro or the Divine Face of Jesus) is brought out from its shrine to the 400-year old Naga Metropolitan Cathedral and the Parish of Saint John the Evangelist (Naga Cathedral) (see Figure 1). The transference of the image is locally called traslacion, literally an act of transferring featuring an allmale ensemble called voyadores.

On the ninth and last day of the novena, the image is returned to its shrine following the Rio Grande de Naga (Naga River) route via a fluvial procession called regata. The voyadores transfer the Divino Rostro first then followed by Ina to the edge of the market where a permanent concrete stage in honor of her has been erected beside the river. In the river, equally fanatic groups of voyadores ferried by colorful bangkas (boats) are waiting. When the flatboat 
reaches its destination at the Shrine, the devotees shout "Viva la Virgen" (Long live the Virgin!) and the images or the Divino Rostro and Ina are carried back to the shrine via the same wagons that brought them to the cathedral on the first day.

As an important religious image of the Catholic community in Naga, the devotees have transformed Ina (the image) into a woman analogous to a respected queen and a venerated divine in need of absolute and ultimate protection - an entanglement of the sacred and the secular in one body. At the same time, the devotees have been continuously constructing or re-forming an ordinary statue or icon into the Ina equivalent of a most prized possession. In the end, this figuration is tantamount to an idolisation expressive of how the woman is theatrically performed as an important figure of the community (Peterson, 2020).

On a different note, the festival seems to perform an othering of women by the very act of not including them in the rites of the traslacion and the regata. Such marginalisation is explored to have a root in the pre-colonial times based on the reports of the Hispanic chroniclers to the King Spain. These reports reveal a celebration of the feminine. In this regard, the devotees constantly navigate what Joseph Roach calls the "three-sided relationship of memory, performance and substitution" (Roach, 1996, p. 43). At the heart of this threefold relationship is surrogation, defined as the "actual or perceived vacancies occur[ing] in the network of relations that constitutes the social fabric" of a particular culture (p. 2 ). In the process of performance is a surrogation wherein the surrogate performer embodies the memory of the original. However, the surrogate is not an exact copy of the original. Following this line of inquiry, the festival's performance of masculinity is proposed to be linked historically to a pre-colonial devotion to a woman who is transformed into Ina in today's Bicol region.

This paper is divided into three parts. The first part is a thick description of the Peñafrancia, beginning with the voyadores's ritual-transfer of both Ina and the Divino Rostro from a local shrine to the Naga Cathedral on the first day. This ends with a descriptive narrative of the performance on the ninth and last day, where the voyadores take the route of Rio Grande de Naga as they return the images back to the shrine. In describing the performance, I highlight that the religious festival signifies a masculinisation of faith in this predominantly Catholic community of Naga.

The second part is an analysis of this masculinisation using focused ethnographic notes from some voyadores and other devotees including women. As presented in the pages of this section, the masculinisation is based on three propositions. First, tradition is the common culprit. Second, women themselves 
consciously avoid being part of the traslacion and the regata for a primary reason of physical frailty. Finally, the restriction of women in the performance produced a theatrical spectacle where a woman is idealised as a queen to be protected and an icon equivalent to a most prized possession: the image of Ina.

The third and final part is a close reading of the performance using a precolonial pretext about the role of women in the islands. In this regard, I look into a potential origin of the Peñafrancia, which is linked to the binukot, a performance tradition where women were veiled for protection and paraded to the local village as a manifestation of honor and pride (Abrera, 2008/2009; de Morga, 1909; Alcina, 1975; De Mentrida, n.d.). It is here where Ina is argued to surrogate the precolonial binukot albeit the primacy of veiling is no longer practised in the contemporary devotion.

In conclusion, it is asserted that the Peñafrancia in today's performance has idealised a figure, which may be perceived as a manifestation of a cultural memory where the performers are keen to remember through performing faith (i.e. panata) what the colonisers archived, antagonised and destroyed in their annotations. More importantly, the ritual and festival is argued to have created a unique sense of Bicolano Catholicism, which is neither dogmatic nor absolutely unorthodox, but an understanding of Catholicism filled with contradictions and multiple negotiations.

\section{Conceiving Cultural Performance}

The Peñafrancia Festival is an example of a cultural performance. Many performance scholars have been attributing cultural performance as a cultural fact and a cultural lens for the understanding of personal identity and communal belonging (Tiatco, 2019; Peterson, 2020). A cultural performance is also viewed as an "imperative of social efficacy" that "theorists have largely concentrated on performance's transformational potential" (McKenzie, 2001, p. 31). As will be explored later, an individual Catholic Bicolano invokes a sense of personal identity in his/her devotion to Ina. At the same time, the devotion is used by the Bicolanos to invoke a sense of community - a gesture of their communal belonging despite multiple affiliations as citizens of the Philippine nation.

On the other hand, Milton Singer (1972) argues that cultural performances are "the elementary constituents of the culture and the ultimate units of observation. Each one had a definitely limited time span, or at least a beginning and an end, an organised program of activity, a set of performers, an audience and a place and occasion of performance" (p. 70). As initially glossed earlier, the Peñafrancia is a nine-day festival preceded by the rite of the 
traslacion, performed onto the streets of Naga City Center and ends with the rite of the regata, performed mostly in the Naga River and enacted by the voyadores with pilgrims, other devotees and even Ina as the audience members and a sacrificial devotion as the axiom of the performance.

From a folklore standpoint, a cultural performance may be gleaned as "an artistic communication in small groups" (Ben-Amos, 1972, p. 14). In relation to this folkloric definition, Deborah Kapchan (1995) also equates folklore to cultural performance because both are repetitive aesthetic practices whose repetition "situates actors in time and space, structuring individual and group identities" (p. 479). In the next pages, it is asserted that despite religious inclination of the festival, several adolescent boys think of the performance as a creative way to assert adulthood - a rite-of-passage communicated among a group of male friends and often among family members. More so, the voyadores, as asserted later, communicate their devotion to Ina as a strategy to perform masculinity.

Cultural performance is also an intervening space between the past and the present, the self and the community, the state and religion, ornament and function, fact and fiction, celebration and solemnity, the sacred and the secular, and other related entanglements. In short, it blurs boundaries of the everyday life and special occasions, making cultural performance a liminal entity (Turner, 1969). A useful concept identifiable with liminal entity is entanglement, mixing and matching different elements together to a point that these elements are no longer recognizable. As indicated in this paper, the Peñafrancia entangles the pre-contact history and colonial history in the present. The current performance of the devotion embodies a past, which was archived in the annotations of the Hispanic chroniclers, appearing in the present through processes of surrogation.

Finally, cultural performance is implicated as an important community narrative. Philip Zarilli (1992) notes, “[p]erformance as a mode of cultural action is not a simple reflection of some essentialized, fixed attributes of a static, monolithic culture but an arena for the constant process of renegotiating experiences and meaning that constitute culture" (p. 108). In the case of the Peñafrancia, it is asserted that the community narrative performed in the Bicol Region implicates a continued gender and devotional performatives.

Since Milton Singer's (1972) introduction of the term cultural performance to the academic domain, cultural performance has evolved into an important observable unit in the study of the individual, society and culture. Since then, cultural performance has become a significant lens which has led "to the throwing off of earlier habits of using culture as a noun and the coming to 
terms with the complexity of recasting it as a verb. In short, the idea of culture has transformed from static object into performance" (Tiatco, 2019, p. 78).

Generally, the emergence of cultural performance as a social idiom in cultural studies, especially in theatre and performance studies, paved the way for a purview that transforms culture into action. In the Philippine context, it is important to note that the concept of culture as performance is not new to the Filipino people, as cultural performances are very prevalent in the cultural and political life of the Filipino people (Peterson 2016, 2020; Tiatco, 2019).

I have proposed elsewhere that to understand the context of Philippine cultural performance, one must look at these performances as processes of panata (vow), pagtitipon (gathering) and pagdiriwang (celebration). Moreover, it is also important to note that these performances are not only treasured because of their spectacular attributions but also because these performances activate the shared values, identities and histories of communities. Philippine cultural performances must be perceived as a "personal creative expression of every community member. However, the personal performance despite intentions, goals and aims becomes public as it is transformed into a ceremonial gathering or a sacrificial vow or a festive celebration" (Tiatco, 2019, p. 79).

\section{Ethnography and Performance: A Conceptual Methodology}

The paper is methodologically informed by ethnography, particularly the emerging field of performance ethnography where the ethnographer explores performance as an imaginative ethnography or the cross-disciplinary meeting of the anthropological and the creative arts in either a theatrical space or any given public space (Elliott \& Culhane, 2017; Kazubowski-Houston \& Magnat, 2018). On the other hand, the ethnographic methodology is framed in the paper in the sense that its subject is a cultural performance in the Bicol Region as understood from the emic perspective of the devotees. While my initial exposure to the festival was in 2015, a formal focused ethnography began in 2016. My arguments about performance, gender and devotion in this paper are based on my observations on the different performances during the nine-day festival in Naga City. At the same time, assertions are based on the narratives of the Bicolanos the voyadores and even women devotees from the aforementioned formal beginning until my most current observation of the festival in 2019.

Anthropologist Julius Bautista and Peter J. Bräunlein (2014) describe ethnography as an act of witnessing where anxieties and crises are also lingering in the act of jotting down notes. My anxieties are coming from the fact that despite attempt at an objective critical analysis, I am also interpreting, conceptualising and intellectualising the observable phenomenon that is the 
Peñafrancia based on my own positionality/ies and sometimes even prejudices as a performance reader. Nonetheless, Bautista and Bräunlein (2014) provide an antidote: "anxieties, crises of relationship, and the experience of outright repudiation in the field are not annoying disturbances of the data-collecting mission (which are usually omitted from the final transcript) but are themselves ethnographic data that are important in and of themselves" (p. 505).

The use of the first-person pronoun " $\mathrm{I}$ " in this paper is important, as it is a methodological and a conceptual decision: it positions my own interpretative reflexivity. More importantly, the discussions that follows are from the point of view of both an outsider of the community and incidentally, also from the point of view of an insider by virtue of being a Filipino Catholic.

As an ethnographer, the intellectualising energy invested in the analysis of the Peñafrancia is not only part of an intellectual activity but also part of the creative domain. Bautista and Bräunlein (2014) write:

[t]he use of the first-person " $\mathrm{I}$ " is a methodological decision that emphasizes an introspective voice in the production of "reflexive" ethnography. Our main point here is to suggest that an awareness of the human instrument is not simply a matter of including the ethnographer's intellectual and personal biography in the analysis. Rather than an exercise in navel gazing, reflexivity involves the ethnographer's recognition of a responsibility to thoughtfully problematize and/or reformulate his or her epistemological practices and categorical apparatus, in a way that is critical of all practices that restrict the role of those he or she encounters in the field as mere "informants" who are passively complicit in his or her empirical regimens. (p. 505)

\section{Traslacion, Prusisyon and Regata}

The traslacion immediately commences after the novena prayer at noontime. As soon as the church bells ring, the priest and his sacristan (church assistants) remove the images of the Divino Rostro and Ina from the retablo (altar). Then the Divino Rostro is brought out first and placed on its andas (wagon). As soon as the Divino Rostro becomes visible to the devotees, the sea of voyadores and equally frenzied devotees from the sidewalks begin their plethora of praises, commonly "Viva! Viva!" (Hail! Hail!) and "Kaawaan mo kami!" (Have mercy on us!).

During the procession, the voyadores rush towards the image to touch it. Some climb on top of the shoulders and sometimes the heads of other voyadores creating a human bridge, the fastest route towards the Divino Rostro. Touching the image is important for doing so guarantees a year of protection, says one 
devotee-voyador. Another informant notes many bring small towels and make sure these towels touch the image. They believe that the Divino Rostro transforms these towels into amulets or lucky charms. One devotee said a lot of them keep the towels inside their homes for a year.

As the andas passes by, mostly women and children on the sidewalks or streets throw handkerchiefs and small towels to the voyadores, who catch these and then rush towards the image. People expect the voyadores to return the fabric to the devotees however they can. Most of the time, the voyador throws the fabric back in the direction where it came from.

Depending which affiliation one belongs to, it is common for a voyador to wear a prescribed uniform, a t-shirt with the inscription of the group's name or an identifier such as the picture of the crowned Jesus or the face of Ina. According to one informant, there are more than a hundred groups of voyadores actively participating in the festival every year. In order to identify the proper affiliation, members of a group wear the same color t-shirts and make sure that the same print is printed on both sides of the shirt.

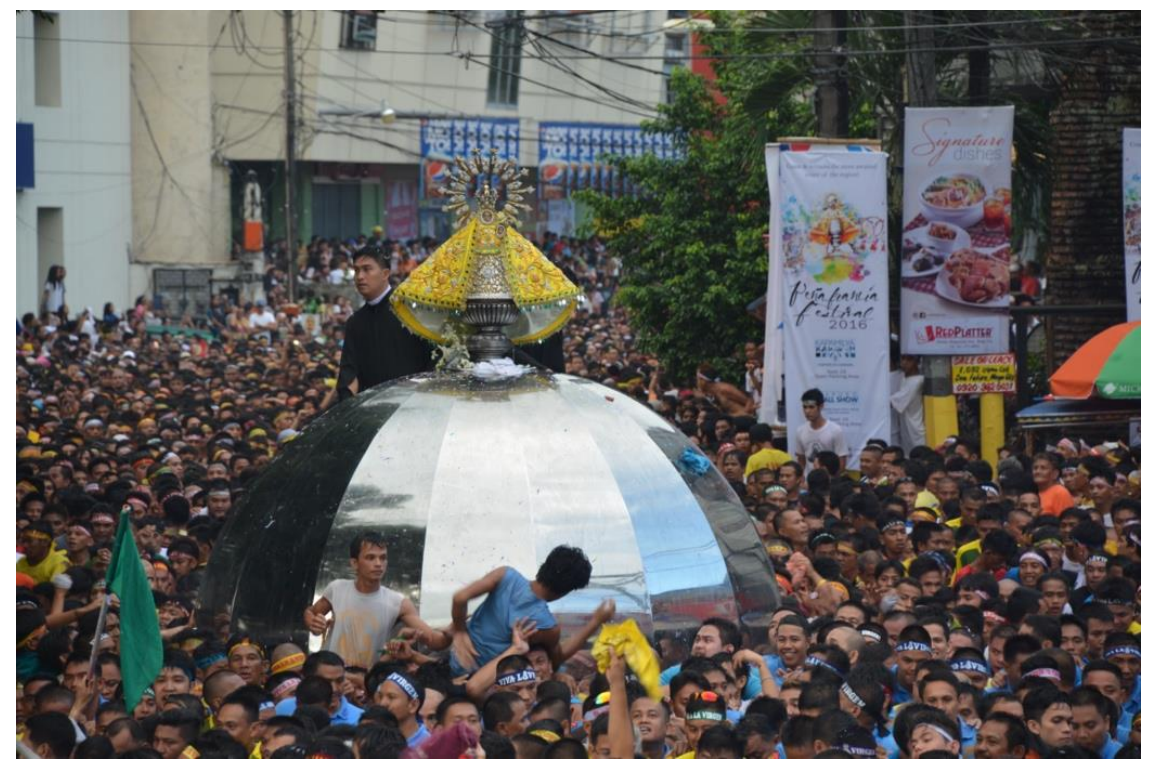

Figure 2: The image of Ina on the andas paraded onto the streets of Naga City (Photo: Sir Anril Tiatco)

After the Divino Rostro is transferred to the Naga Cathedral, the voyadores rush back to the shrine for the traslacion of Ina. The church bells once again peal. The priest and his assistants bring the image of Ina out of the church to install it on its andas. Like for the Divino Rostro, the air fills with roars of 
"Viva, Viva!" and other shouts of praises. The voyadores ready themselves as they are expected to pull the andas safely back to the cathedral.

In anticipation of Ina, the excited devotees on the sidewalk and along the streets begin to wave white garments. A lot of these are imprinted with a picture of Ina. According to an informant, the waving invites Ina to look at them, to pity them for their sufferings and pains. Others mentioned that the waving collects blessings from Ina. Several believe that the divinity of Ina is present in her picture printed on the garments.

Like the earlier procession of the Divino Rostro, the voyadores begin to pull the andas of Ina through the streets of Naga City. Some devotees also throw handkerchiefs, towels, and other garments to the voyadores, hoping that the voyadores bring these closer to Ina. Just like the earlier procession, touching the image of Ina is difficult because the number of voyadores increases up to 20,000 . An informant remarked: "sususugin mo lahat 'yun para lang makarating ka sa karosa" [You have to bump and defend yourself from these men just to reach the wagon of Ina] (see Figure 2).

Like the image of the Divino Rostro, the best way to reach Ina is to climb on top of each other. I observed in all my visits that young voyadores are eager to jump over the shoulders of the others and rush towards the manto (hem) of Ina. While most fail to touch the garb or come near the image, a few younger devotees succeed as voyadores loudly shout "Viva!" after every touch.

As soon as the voyadores transfer Ina from its shrine to its new home for nine days at the Naga Cathedral, women called the prayer warriors take over the veneration. They pray the rosary, clean the manto, and collect donations. In my 2017 visit, these women paraded Ina on the streets, traversing the church grounds to the marketplace to the town plaza and back to the church. No man was allowed to participate in this procession.

On the last day of the Peñafrancia, the Divino Rostro and Ina are once again paraded on the streets to the river for a fluvial procession popularly labeled the regata (from regatta, a boat race). In the regata, two types of voyadores are present: those on land and those on water. The voyadores on land are responsible for the transfer of both the Divino Rostro and Ina from the Naga Cathedral to the Rio Grande de Naga. Ferried by colorful bangka (boats), those on the water are responsible for the procession over a four-kilometer stretch of the river bringing the images back to the shrine (see Figure 3). 


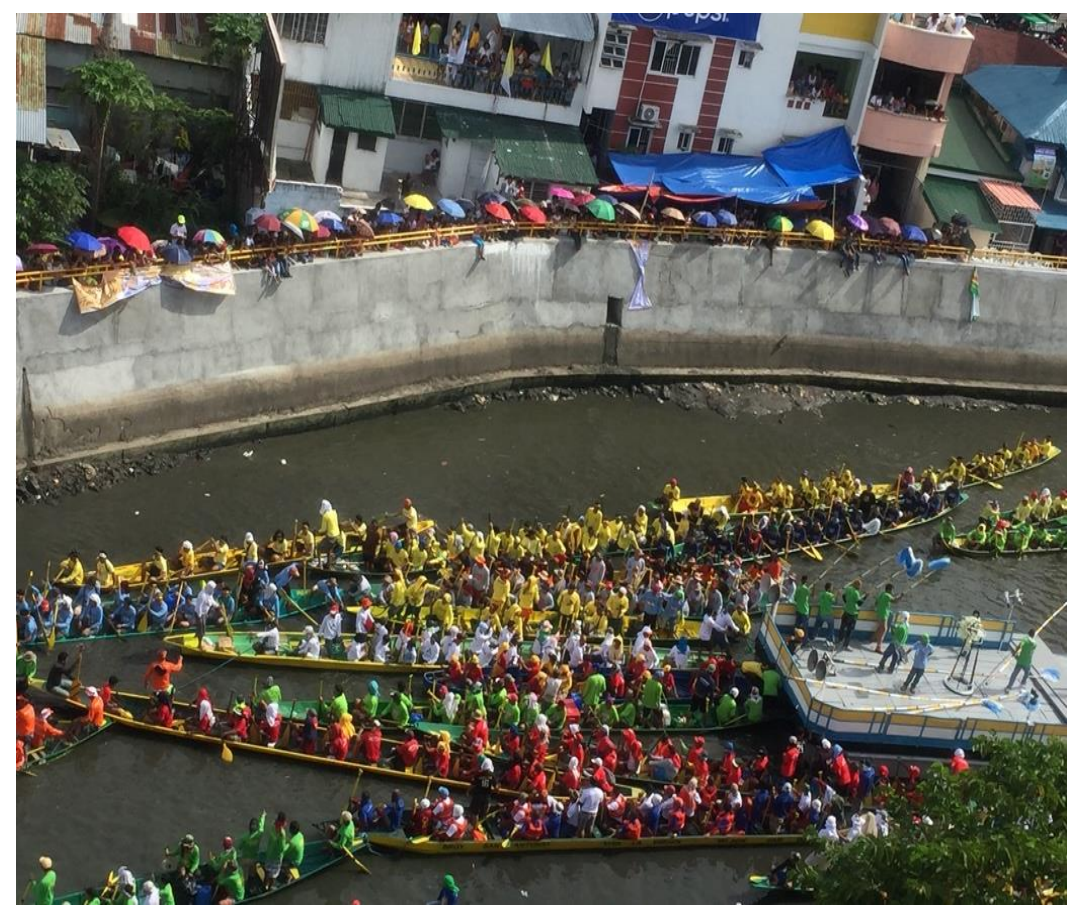

Figure 3:

The voyadores waiting for the Divino Rostro and Ina on the banks of the Naga River (Photo: Sir Anril Tiatco)

Usually by 3 in the afternoon, devotees start to line-up at the riverbank. Some establishments along the river open their doors to devotees to wait for Ina to bless them. In 2016, a popular hotel along the river just adjacent the starting point of the regata allowed up to a hundred devotees on its rooftop giving them a clear view of the procession.

Many private homes along the river also open their doors to devotees. As the occasion is a fiesta, even strangers are invited to the handaan (banquet). Maida Pineda (2005) explains "when the fiesta comes, everything has a sparkle to it. It is the right time to meet Filipinos at their best" (p. 74). Pineda (2005) advises visitors: "Be prepared to eat, eat and eat. Filipinos serve their finest food during fiesta. [...] There seems to be an endless supply of food. The hosts make sure they never run out, as it is embarrassing to do so [...]" (pp. 75-76). Pineda (2005) also advises, "Accept an invitation from a stranger to join the banquet. If a local person finds out you have not eaten lunch or have no place to go for lunch, you will surely be invited inside their house for a meal, even if you are a stranger" (p. 76).

For many, opening the doors of the residences is an act of hospitality, a common practice during any fiesta in the archipelago: "a sense of hospitality for 
the "other" - a welcoming gesture for taga-dayo (non-residents), including foreigners" (Guevarra, Gatchalian, \& Tiatco, 2014, p. 9). For many visitors to Naga City, this hospitality enables them to have a closer view of Ina as she passes by on the river.

Everyone is carrying candles and handkerchiefs, mostly white, in anticipation of Ina's parade. The voyadores are aboard colorful paddleboats pulling the large pagoda of the Divino Rostro and Ina via a long and a sturdy rope. Devotees and pilgrims raise their handkerchiefs and wave, they shout as the pagoda gets nearer.

Once the image is transferred back to its shrine, a Holy Mass is celebrated presided by the bishop of the archdiocese of Caceres. The priests from the different parishes of the Bicol region accompany the bishop in this final Eucharistic celebration on the ninth and final day.

\section{The Gendered Devotion: Is it a Man's World?}

"Panata na namin ang maging tagapagtanggol ni Ina!" [It is our vow to protect Ina] remarked a semi-drunk devotee. When asked why they have to protect Ina, he quips "Panata nga - sakripisyo, ako para sa aking asawa" [As I said, it's a sacrificial vow - I personally sacrifice for my wife].

Participating in the festival is a performance of panata, a sacrificial and religious performance enacted by a voyador for himself or his loved ones. Often, voyadores are performing this painstaking panata for a sick loved one such as an informant whose wife was diagnosed with cancer the first year, he joined the ritual-festival in 1998. In other cases, a voyador joins the traslacion and regata because of family tradition - male members of the family are devotees. For example, Frank, a 50-year-old informant has been participating since his teenage years.

There is an obligatory reciprocity "based on a strict connection between social benefits and social obligations" (van der Veen, Achterberg, \& Raven, 2012, p. 37). Ina is a mother who has a "social obligation" to provide for her children. In return, she receives veneration and protection from the voyadores. This notion of reciprocity is common in many Catholic communities. In the town of Calabanga, also in Camarines Sur, for example, Fenella Cannell recorded that the panata of the Catholics is synonymous with "promise" which is "made during a moment of crisis. The person calls on the help (tabang) of God or the saints [...] and promises something in return" (1999, p. 191).

One thing is also clear in the panata: the devotee is performing a sacrificial act to communicate an intention or a petition to his or her God. Oftentimes, the panata becomes the axiom of any folk-Catholic cultural 
performance. This sacrificial act is "enacted for the good of the devotee himself or herself, for a loved one (i.e. usually a sick loved one), or for the community" (Tiatco, 2016, p. 73).

The bulk of literature on Philippine Catholic cultural performances such as rituals, festivals, and spectacles are framed within this theological dimension of panata (Alcedo, 2007; Cannell, 1999; Dela Paz, 2008; Gonzales-Villegas, 2008; Peterson, 2016; Tiatco, 2011, 2016). Nonetheless, panata must also be looked at as a socio-cultural and even a political idiom primarily because "Christianity's meaning is always undetermined by any single historical, social or ideological context in which it is deployed" (Cannell, 2006, p. 43). In this regard, the performance of panata in the Peñafrancia may be figured as a cultural potency leading towards an understanding of what it means to be masculine and even feminine, at least in the worldview of the Bicolanos.

Frank has an 18-year-old son who joined the traslacion in 2016. When asked about his joining the voyador the first time, he notes that his participation is "panata na ng pamilya" [a family devotion]. Significantly, this first-timer exclaimed in full pride "panahon ko nang maging tunay na lalaki. Ang tatay ko at lolo ko ay mga voyadores. Bata pa lang ako alam ko na dapat din akong sumama sa traslacion at kailangan kong mahawakan ang manto ng Ina" [It is my time to become a man. Both my father and grandfather are voyadores. When I was younger, I knew that I should also be part of the traslacion and I have to touch Ina's cloak]."

His remark is both fascinating and intriguing since the teenager is convinced of his becoming a real man only if he becomes like his father and grandfather: veteran voyadores. More so, it is important for the young devotee to touch the manto of Ina since both his father and grandfather touched the manto of Ina during their respective participations in the Peñafrancia.

Incidentally, the young man was not able to touch the manto that year. Despite that, he is not giving up since "okay lang yun, sina tatay matagal din naman bago nahawakan ang manto" [That is not a problem. It also took some time before dad and grandpa were able to touch the garb of the Virgin].

The young man was with his barkada (peers) when he joined in 2016. They were eight in total and they all joined a larger group composed of 42 members. They wore orange t-shirts with the face of the Divino Rostro printed on it. Like Frank's son, five members of the eight young men participated in the festival because of a particular belief that they too have to become a "tunay na lalaki" [real man].

On the other hand, these youngsters analogise their participation in the traslacion and regata to their experiences of circumcision, locally known as pagtutuli. "Mabibinyagan na ako, sa wakas," [It is my baptism, finally!] exclaimed 
an enthusiastic 17-year-old male devotee when asked if he was excited to participate in the performance. The teenager-devotee continues: "Parang ikalawang pagtutuli baga" [Like a second circumcision]. Another informant agrees and even claims that "yung sakit mula sa sugat ng tuli ay sakit naman ng katawan dito. Pero parehong sakit at hapdi din lang naman yun. Minsan masusugutan, minsan may mapipilay - pero yung namamaga ang katawan mo, kagaya lang nung sa tuli, hanggang isang linggo yun" [if in circumcision is caused by the wound in the genitalia, the pain in the festival is caused by fatigue. However, they are the same pain: smarting and aching. Sometimes, you also get wounded, sometimes even fractured. For sure your body will ache and get swollen just like the penis after a circumcision. And the pain goes on for a week].

The analogy is not surprising because Filipinos perceive circumcision as the boy's "coming-of-age". More so, it is the recognised norm in the Philippines for boys to enter puberty or pagbibinata (adolescent period in a boy's life) in the vernacular. Normally, a Filipino boy is circumcised before entering high school, when he is about eleven or twelve years old. The dual-rite in the Peñafrancia is also a coming-of-age performance, the next step so to speak. In a way, it is performed in anticipation for these young adults to officially proclaim that they indeed have stepped into adulthood.

Nevertheless, pagtutuli is not connected with religion. Majority of the Filipino people are Roman Catholics and the religion does not require its male members to be circumcised. Pagtutuli is a social norm that is followed by almost everyone and it is believed that the Muslims introduced the practice during the pre-colonial times.

In many urban centers, medical practitioners in a hospital or a clinic conduct the pagtutuli. But most agricultural towns or rural areas, pagtutuli is done via the tradition of the pukpok, where the circumciser rests his knife lengthwise across the foreskin of the boy and then a quick blow is made with a stick, slicing the upper foreskin into two and exposing the head of the penis.

Usually, the latter is a painful experience that those who undergo such rite boast to possess more braveness and toughness compared to those who are circumcised in a clinic. This is because the pukpok does not use any anesthetic. The boy undergoing the rite has to endure the pain caused by the striking of the knife while the boy undergoing a circumcision in a clinic experiences minimal if not no pain at all due to the anesthesia injected on the penis. Enduring the pain is deemed equivalent to bravery and toughness. As in the case of an informant who joked during the fieldwork: "Ako pukpok, siya sa clinic lang" ["I was circumcised through the rite of the pukpok. His was done only in a clinic"]. The emphasis in this quotation is my informant's use of lang, which loosely translates as only in 
English. However, the context in the Tagalog language is both a reference to mockery and pride. My informant by emphasising lang is mocking his friend for being coward for not having endured the pain from the pukpok rite.

To ease the pain of the pukpok, the boys are commonly asked to chew guava leaves. When the circumciser strikes the foreskin, the boy being circumcised is asked to spit the leaves and the circumciser rubs the chewed leaves to the wound caused by the sudden striking of the knife. The boy then is asked to bathe to a nearby river as also part of the healing process.

More than this "coming-of-age" association, the rites of the traslacion and the regata are also both manifestations of embodied pain, which as most Filipinos assert as a sign of pagiging tunay na lalaki (the becoming of a real masculine). The pain is often associated with tibay (toughness), tapang (courage) and lakas (strength) - some important traits often a Filipino would hear as exemplary to the ideal Philippine masculine. An uncircumcised boy is often ridiculed for not performing toughness, courage and strength. In the same way, toughness, courage and strength are also performed in the Peñafrancia: a devotee swarms in a sea of other masculine bodies to the point of almost being trapped similar to a stampede as he attempts to touch the manto of Ina. The same young adult informant jokingly stated that any male member in his family or in his neighborhood who has not participated in the rites as a young voyador is often thought of being sissy and a coward. Agreed by his peers: no young male member in their community would want to be associated with these nonmasculine traits.

In the pagtutuli, particularly the practice of pukpok, the pain is commonly described as mahapdi (stinging). Others describe the pain as an experience of smarting and tingling. On the other hand, the physical pain experience in the Peñafrancia is described by the lads to be similar to the experience of bodily cramping and throbbing. This is because the pain is coming from the soreness of the muscles caused by fatigue. Nonetheless, both physical pains are experienced often for the sake of the opposite sex. Male adults often tell their male children that pagtutuli is beneficial to their future martial affairs: a circumcised penis is more hygienic, and it is more pleasing to one's sexual partner. On the other hand, the performed pain in the Peñafrancia is a display of courage, toughness and strength of the masculine psyche at the outset plus as earlier stated a religious intention of being the protector of the most important woman in their land.

Also observed during the festival, most of the devotees if not all are semidrunk. The smell of alcohol (beer and lambanog in particular) overpowers the smell of sweat from the sea of frenzied men as they push, pull and carry each 
other while pulling the long rope tied to the andas of the Divino Rostro at first and then to that of Ina.

Consequently, to ease the experience of pain, these young boys join the adult voyadores in a tagayan or a drinking session. Usually, the voyadores drink beer and local wine called lambanog. It is believed that the ingested alcohol from the local beer and the local wine becomes anesthetic-like which will ease the fatigue and the body aches that may be encountered during the traslacion and the regata.

In Philippine popular culture, tagayan is associated with the local macho culture. At the same time, it is perceived to be the only avenue for Filipino men to socialise with other men devoid of the fear of being accused of homosexuality (Valledor-Lukey, 2012). Despite claims that homosexuality in the Philippines is non-issue, the homosexual, locally called the bakla is still a figure of ridicule and has a social stigma in the archipelago (Garcia, 2009).

Tagayan is also typically associated with toughness, courage and strength. In many instances, combining all these three traits performed in the masculine Filipino body is a local sense of machismo's self-esteem if not selfworth (Basham, 1976; Valledor-Lukey, 2012). For anthropologist Richard Basham, this is the cult of the male or a belief that these traits possess an ideological belief of superiority over the woman (1976, p. 126). At the outset, this perhaps is one primary reason why the festival's dual-rite is dominated by the masculine world: an indication of masculine ego-guarding.

As a performance of religious intention, the performed masculinity is based on an implicit negotiation of bodily self-mortification and prayer, which as religious scholars put it, central to the narrative of Christianity/Catholic worldview: Christianity is "founded upon the belief that Jesus Christ, a divine being, underwent the excruciating torment of state sanctioned torture, thereby enduring the limits and vulnerability of the human body. It is founded, also, on Christ's transcendence of pain and the mortality of the body itself" (Bautista, 2011, p. 152).

Ironically, this performance of masculinity in Bicol is something, which is not absolutely Catholic if we look at the context of dogma and theology. The dogma calls for inclusivity more than exclusivity. The doctrine of inclusivity is a welcoming gesture to everyone. Often, the Catholic dogma cites the Pauline epistle as basis of the doctrine. Even philosopher Alain Badiou (2003) finds this doctrine as the potency of a new truth: the cosmopolitan potential where "something that is open to everybody, a collective determination, the realisation of a separation in a universal field" (p. 40). In his letters to the Galatians, Paul said "there is no Jew, no woman, no man, no slave, no freeman" (Gal. 3:28). If 
this is the new truth, a new universal potential, then, why are the women in the performance in this Catholic nation are excluded?

\section{Gendered and Theatricalised Performance: Recuperating the Pre-colonial Past?!}

Based on what was already articulated, the rites of the traslacion and the regata in the Peñafrancia seem to have normalised an understanding of masculinity as a privileged position. The performance pushes forward an ideology where women are represented as the opposite of toughness, courage and strength. The normalisation seems real because women devotees themselves fear to be part of a purportedly stampede caused by the performative chaos of trans-locating the image of Ina on ground on the first day and a combination of land and fluvial processions on the ninth and last day of the ritual and festival.

One female informant for instance states: "You will not see women joining in the traslacion. These men are rowdy. Imagine you have to climb on top of each other just to touch the manto." She continues: "Pag ganyan na, wala silang sinasanto!" [On these occasions not even the holiness of the saints is recognised]. Another exclaims, "Wala akong lakas upang mambitbit ng kapwa namamanata! Kasama naman kami sa panata ng mga asawa, anak, tatay namin" [I do not have the strength to carry other devotees on my shoulder. Anyhow, we are included in the panata of our husbands, sons and fathers]. Annually, some devotees are taken to the hospital after surviving a fall and stampede in an attempt to go near the andas to touch the manto. Surprisingly, no recorded death has been reported to this day.

A devotee and wife of a voyador Virgina links the no-woman voyador to a historical memory: "Simula noong magkaisip ako, ganyan na ginagawa dito. Basta ang mga lalaki sa traslacion at mga babae may madaling araw na prusisyon naman kasi" [As long as I remember, it has always been like that. Male devotees to the traslacion and female to the early dawn procession]. Manang Maring, a candle seller at the Naga Cathedral narrates that sometime in the 1980s, the pagoda sank during the regata. She continues: "May isang babae kasi na hindi napansin ng mga tao na nakapasok sa pagoda. Mukhang lalaki kasi. Parang tomboy kasi. Nagtampo ang ina" [There is a girl who joined the pagoda. Nobody noticed because she looked like a girl - tomboyish look. The Queen got jealous, that's why].

I deduce three primary reasons as to the assumed exclusion of women in the performance. First, tradition is the common culprit. Informant Frank mentions, "Tradisyon na iyan, nakagisnan na kaya ganon!" [It has always been like that - it's tradition!]. Similarly, Virgina remarks: "It has always been like that pamana na sa amin ng mga matatanda namin!" [The performance is part of our 
heritage - transmitted by our elders to us]. Often, tradition and heritage are used to signify "glorious past" in the present. Nonetheless, people tend to forget that these are also contested concepts. Tradition may be an intangible object passed on from one generation to another, but it is also invented, and it is continuously reinvented (Smith, 2006; Harrison, 2010; Dela Santa \& Tiatco, 2019).

Second, women themselves consciously avoid being part of the traslacion and the regata for reason of physical frailty. Virginia notes: "Hindi naman kakayanin ng mga kababaihan yung ginagawa ng mga voyador - tingnan mo naman, hinihila yung tali tapos nagsisiksikan sila upang maabot ang manto ng Ina" [Female devotees could never perform the physical demand of the tradition, compared to the strength of the voyadores. Just look at the male devotees - they carry with them the wagon and they rush to touch the garb of the lady]. In this regard, the maintenance of the tradition and the physical demand of the ritual are often used as the culprits on the non-participation of women.

Finally, the restriction of women in the performance produced a theatrical spectacle where a woman is idealised as a queen to be protected and an icon equivalent to a most prized possession. For instance, informant Linda remarked: "Reyna si Ina. Dapat siya lang ang babaeng bida" [Ina is the queen. She should only be the female protagonist in the ritual-festival]. Frank also explains that "mabilis magtampo ang Ina, siya ang reyna! Dapat walang ibang papansinin" [the Lady is very sensitive and jealous. The attention must only be focused on her], justifying why no woman is allowed to join the voyadores.

This seemingly exclusion of the women may be deemed as a continuation of a pre-colonial practice. The pre-colonial women of the islands, especially in the Visayas and in Bicol had significant roles in religious ceremonies and oral cultures. The women were respected and venerated as observed in the precolonial traditions of the babaylan and the binukot. The babaylan is a pre-colonial priestess and a seer. In many occasions, she also acted as a community mediator (Alcina, 1975; Jocano, 1998; Scott, 1994). On the other hand, the binukot is a tradition where women were veiled for protection and paraded to the local village as a manifestation of honor and pride (Abrera, 2008/2009; de Morga ,1909; Alcina, 1975; De Mentrida, n.d.).

Each time the woman was taken away from her house, her face was covered because it was considered the sacred abode of the gods. She was also not allowed to step on the ground, considered dirty by the pre-colonial communities. The male members of a community carried her wherever she went (Abrera, 2008/2009).

During religious ceremonies, these veiled women were paraded before their gods and/or before the village chieftain called datu of the community. In 
some instances, these veiled women were paraded in other communities, especially if there was an interest in creating an alliance. The binukot were the most prized possessions of every household that in return for marriage, the other party was required to pay what pre-colonial societies called dote (dowry).

Fast-forward to present-day Bicol, veiling is no longer practiced but protecting, guarding, parading and carrying the woman before the common people is still performed by community members. Nevertheless, a single woman through the Lady of Peñafrancia surrogated the binukot in this Philippine region. This woman, like the pre-colonial binukot is now hailed as the most important woman of the community. Parading her onto the streets of Naga City and carrying her on the andas and on the pagoda are extension of the pre-colonial veneration, prestige and protection. One informant claims that Ina has to be placed on an andas because only the lowly can step into the dirty streets of Naga City.

The voyadores at the outset are performing machismo but implicitly they are also performing a sense of responsibility, respectful deference to spouse, women, and the elderly, integrity, emotional and physical strength, and even a sense of community. The Peñafrancia Festival, in a way, is a manifestation of a cultural community in which the pre-colonial lifeways of its members are recuperated through expressive bodily movements. At the same time, the legacy of Hispanic Catholicism is decolonised through this re-articulation of an indigenous past. This, for Joseph Roach, is a combination of surrogation and kinesthetic imagination, which can be traced in the genealogy of performance:

expressive movements as mnemonic reserves including patterned movements made and remembered by bodies, residual movements retained implicitly in images or words (or in the silences between then), and in imaginary movements dreamed in minds, not prior to language but constitutive of it, a psychic rehearsal for physical actions drawn from a repertoire that culture provides. (Roach, 1996, p. 26)

The Peñafrancia, through Ina, assists the community members to remember its indigenous culture, which includes norms and traditions involving religion and gender. The ritual-festival also assists the devotees in reimagining Catholicism as a performance more than a dogma.

\section{Concluding Reflections}

As earlier pointed out, today's performance of the Peñafrancia has idealised a figure, which may be perceived as an extension of the binukot tradition in many 
communities in the Visayas and in Bicol. An important figure in the community, the binukot was venerated and protected to a point that her feet were prohibited to even touch the ground. She was a figure of prestige - considered a very prized possession. A male member even had to pay for a huge sum of money to win her for marriage.

In the tradition of the binukot, the male members had a very significant role. They made sure she was protected and kept unharmed from the throngs of everyday life. Today, the binukot is surrogated and reimagined in the performance of the Peñafrancia. The Ina is the substitute for the binukot albeit the practice of veiling is no longer performed in today's devotion and festival. Like the revered woman in the indigenous tradition, Ina is made sure she is protected. The male members ensure Ina does not step on the ground. The male members ensure Ina is revered appropriately. The voyadores ensure Ina is recognised as the most important woman in the community. They ensure that she is transformed into a queen, a mother and a Divine.

In this sense, the Peñafrancia performers make implicit use of figuration to conceive in detail the process by which an entity, in the case of the ritual and festival, the image of Ina, is given a particular form. In my reading, this is a creative endeavor "in ways that speak to the making of worlds" (Castañeda, 2002, p. 3). A figure is the simultaneously material and semiotic effect of specific practices. The figure of Ina is based on the material and the semiotic effect of a highly gendered performance.

Looking into the performance of the ritual and festival, Ina is the productive space where Bicolanos fill in to construct their own identity, sociality and even their inclination as members of the Catholic community. Today, Bicolanos identify their personal identities to their devotion to the Lady of Peñafrancia. At the same time, this devotion is the basis for the construction of their communal identity. Frank testified that "ang pagiging Bicolano o Bicolana ay pagiging deboto ni Ina" [to be a Bicolano or a Bicolana is to surrender himself or herself to Ina].

In another way of putting it, this figuration of Ina creates a unique sense of Bicolano Catholicism, which is neither dogmatic nor absolutely unorthodox. It is an understanding of Catholicism filled with contradictions and multiple negotiations. This performance may be conceived as "the constantly reinvention of the "heretical". At the same time, the performance speaks about how members perform both the orthodox and the unorthodox, the dogma and the popular belief, the institutionalised and the traditionalised in creative, contested, and multiple ways" (Tiatco, 2016, p. 20).

Finally, in the performance of the Peñafrancia, the devotees have figured 
Ina as material and a semiotic site where Bicolanos (community members) construct not only the figure of Ina as the queen, the mother and the divine but at the same time, the figuration enabled to assist the community member to their particular claims especially on ideas of difference - in areas of gender, devotion and theatricalised ritual and festival.

\section{References}

Abrera, M. B. A. (2008/2009). Seclusion and veiling of women: A historical and cultural approach. Philippine Social Science Review, 60(1), 33-56.

Alcedo, P. (2007). Sacred camp: Transgendering faith in a Philippine Festival. Journal of Southeast Asian Studies, 38(1), 107-132. https://doi.org/10.1017/S0022463406000956

Alcina, F. I. (1975). La Historia de las Islas e Indios Visayas. Madrid: Instituto de Historico de Manila.

Badiou, A. (2003). Saint Paul: The foundation of universalism (R. Brassier, Trans.). Stanford: Stanford University Press.

Basham, R. (1976). Machismo. Frontiers: The Journal of Women's Studies, 18(3), 126143. Retrieved from https://www.jstor.org/stable/3346074

Bautista, J. (2011). The bearable lightness of pain: Crucifying oneself in Pampanga. In A. Danczak \& N. Lazenby (Eds.), Pain: Management, expression and interpretation (pp.151-159). Oxford: Interdisciplinary Press.

Bautista, J., \& Bräulein, P. J.. (2014). Ethnography as an act of witnessing: Doing fieldwork on passion rituals in the Philippines. Philippine Studies: Historical and Ethnographic Viewpoints, 62(3-4), 473-498.

Ben-Amos, D. (1972). Toward a definition of folklore in context. In A. Paredes, \& R. Bauman (Eds.), Folklore (pp. 3-15). Austin: University of Texas Press.

Cannell, F. (1999). Power and intimacy in the Christian Philippines. Quezon City: The Ateneo de Manila University Press.

Cannell, F. (Ed.). (2006). Anthropology of Christianity. Durham: Duke University Press.

Castañeda, C. (2002). Figurations: Child, bodies, worlds. Durham: Duke University Press.

Dela Paz, C. (2008). Poon at panata: Sining at paniniwala sa Mahal na Senyor ng Lucban, Quezon. Philippine Humanities Review, 10, 105-120.

Dela Santa, E., \& Tiatco, S. A. P. (2019). Tourism, heritage and cultural performance: Developing a modality of heritage tourism. Tourism 
Management Perspectives, 31, 301-309.

De Mentrida, A. (n.d.). Diccionario de la lengua Bisaya Hiligueina y Haraya de la Isla de Panay. Chicago: Photoduplication Service, Newberry Library.

De Morga, A. (1909). Sucesos de las Islas Filipinas. Madrid: V. Suarez.

Elliott, D., \& Culhane, D. (2017). A different kind of ethnography: Imaginative practices and creative methodologies. Toronto: University of Toronto Press.

Garcia, J. N. (2009). Philippine gay culture: From binabae to bakla, silahis to MSM. Hong Kong: Hong Kong University Press.

Gonzales-Villegas, S. (2008). The myth and piety in Maytinis: A ritual of Christmas celebration in Kawit. Philippine Humanities Review, 10, 139-180.

Guevarra, S. V., Gatchalian, C. F., \& Tiatco, S. A. P. (2014). Performing cosmopolitan entanglement in the Philippine pista: Sariaya Agawan Festival. Social Science Diliman, 10(2), 1-29.

Harrison, R. (2010). The Politics of heritage. In R. Harriaon (Ed.), Understanding the politics of heritage (pp. 154-196). Manchester: Manchester University Press in association with the Open University.

Kapchan, D. A. (1995). Performance. Journal of American Folklore, 108(430), 479508. https://doi.org/10.2307/541657.

Kazubowski-Houston, M., \& Magnat, V. (2018). Introduction: Ethnography, performance and imagination. Anthropologica 69 (2), 361 - 374.

McKenzie, J. (2001). Perform or else: From discipline to performance. London: Routledge.

Peterson, W. (2016). Places for happiness: Community, self and performance in the Philippines. Hawai'i: University of Hawai'i Press.

Peterson, W. (2020). Dancing, marching and baton twirling with the Virgin: Performing community at the Peñafrancia festival in the Philippines. Australasian Drama Studies 76, 24-61.

Pineda, M. (2005). Do's and don'ts in the Philippines. Bangkok: Trans-Atlantic Publications, Inc.

Roach, J. (1996). Cities of the dead: Circum-Atlantic performance. New York: Columbia University Press.

Scott, W. H. (1994). Barangay: Sixteenth-century Philippine culture and society. Quezon City: Ateneo de Manila University Press.

Singer, M. (1972). When a great tradition modernizes: An anthropological approach to modern civilization. New York: Praeger Publishers.

Smith, L. (2006). Uses of heritage. New York: Routledge.

Tiatco, S. A.P. (2011). Situating Philippine theatricals in Asia: A critique on the Asian-ness / Philippine-ness of Philippine theatre(s). JATI: Journal of Southeast Asia Studies, 16, $133-152$. 
Tiatco, S. A. P. (2016). Performing Catholicism: Faith and theater in a Philippine province. Quezon City: University of the Philippines Press.

Tiatco, S. A. P. (2019). Panata, pagtitipon, pagdiriwang: A preliminary contextualization of cultural performances in the Philippines. Humanities Diliman, 16(1), 54-81.

Turner, V. (1969). The ritual process: Structure and anti-structure. London: Routledge.

Valledor-Lukey, V. V. (2012). Pagkababae at pagkalalae (Femininity and Masculinity): Developing a Filipino gender trait inventory and predicting self-esteem and sexism. Ph.D. thesis, Department of Child and Family Studies, Syracuse University, Syracuse, United States.

Van der Veen, R., Achterberg, P., \& Raven, J. (2012). Contested solidarity: Risk perception and the changing nature of welfare state solidarity. In R. Van der Veen, M. Yerkes, \& P. Achterberg (Eds.), The transformation of solidarity: Changing risks and the future of the welfare state (pp. 31-48). Amsterdam: Amsterdam University Press.

Zarilli, P. (1992). For whom is the king a king? Issues of intercultural production, perception and perception in a Kathakali King Lear. In J. Roach, \& J. Reinelt (Eds.), Critical theory and performance (pp. 108-134). Ann Arbor: University of Michigan Press. 